\title{
ARTICLES OF THE MEJELLE ON SALAM CONTRACT: JURISTIC EVALUATION AND APPLICATIONS
}

\author{
Md. Habibur Rahman ${ }^{1}$ \\ Muhammad Amanullah ${ }^{2}$
}

\begin{abstract}
The Majallat al-Ahkām al- 'Adliyyah, known as the Mejelle, is the code of Islamic civil transactions which was prepared under the auspices of the Ottoman Caliphate. This code was established based on the Hanafi School of Islamic law. However, people, who follow other than the Hanafi School, are reluctant to rely on the Mejelle even though they are interested to know the stands of their respective School of Islamic law on the articles of the Mejelle. Thus, considering the importance and relevance of Salam contract to the contemporary context, the paper attempts to conduct a juristic evaluation of the articles of the Mejelle on salam contract along with an investigation of its contemporary applications. Salam is a sale contract in which the commodity's delivery is deferred until a defined period, while the buyer must settle the payment upon the contract's conclusion. Although the general principle says that sale of something which is not possessed and not present is not permissible, salam contract is made valid as an exception from this, considering the need of the people. The study follows a qualitative approach and uses the content analysis method to
\end{abstract}

1 Senior Lecturer, Faculty of Business and Management, Universiti Sultan Zainal Abidin, Kampung Gong Badak, 21300, Terengganu, habiburrahman@unisza.edu. my, hrnizamee10@gmail.com

2 Professor, Department of Fiqh and Usul al-Fiqh, Kulliyah of Islamic Revealed Knowledge and Human Sciences, International Islamic University Malaysia, P.O. Box 10, 50728, Kuala Lumpur, amanullah@iium.edu.my 
achieve the objectives. For data source and analysis, the study consults with related classical and contemporary literature. The study finds that in general, the articles of the Mejelle on salam contract conform to the prominent Schools of Islamic law. Among the notable contemporary applications of salam contract are salam financing, parallel salam, salam șukukk, salam in short selling, and so forth.

Keywords: salam, schools of Islamic law, the Mejelle, parallel salam, salam șukūk

\section{INTRODUCTION}

The Mejelle was composed between 1869 and $1876 \mathrm{CE}$ as part of the legislative process of the tanzima àt (a period of reformation of the Ottoman Empire between 1839 and 1876CE) initiated by the Ottoman Caliphate. It represents an attempt to codify the Hanafì fiqh which deals with civil transactions (mu'ämalät). The codification was the work of a Commission of Jurists, headed by Ahmad Djevdet Pasha, Minister of Justice of the Ottoman Caliphate. ${ }^{3}$ The Mejelle contains 1851 articles that encompass legal (Shariah) provisions for various civil transactions, in an organized legal form containing fiqhi $\bar{\imath}$ issues which were dispersed and scattered in fiqh books. Actually, in fiqh books the Shariah provisions are discussed with long details of arguments and evidence, while they are not organized and presented as like the legal codes. Hence, the Mejelle actualized a great legislative task, and bridged a big gap in the judiciary and the lawful transactions that proved the greatness and prestige of Islamic jurisprudence. In fact, the Mejelle is considered as a proof of the flexibility of Islamic law in a sense that it can accommodate the changes of time. Thus, it was a significant achievement for Islamic jurisprudence and its reformation which rejoices the hearts of scholars and Muslims in general. ${ }^{4}$

The Mejelle discussed many jurisprudential topics like sales, leasing, suretyship, transfer of obligation, pledge, deposits, gift, wrongful possession and destruction, unlawful compulsion and pre-emption, joint ownership, agency, compromise and release, acknowledgment, actions, proofs and oaths

3 Tyser, C. R., Demetriades, D. G. \& Effendi Ismail Haqqi, 'Forward', by S. A. Rahman, H. Pk., in The Mejelle; being an English Translation of Majallah alAhkām al-'Adliyyah and A Complete Code on Islamic Civil Law (Lahore: Law Publishing Company, n.d.), ii.

4 Mūsā, İthār, 'Nūṣūṣ wa Mawārid Majallat al-Aḥkām al-'Adliyyah fĩ Sūrriyā', https://www.mohamah.net/law, accessed on 12 November 2020. 
and lastly discussion on a judge and his duties. The first Book of the Mejelle is on sales. It starts from the article (101) and ends at the article (403) and consists of an introduction and seven chapters. Under the book of sales, there is a section for salam contract, where the Mejelle discussed the essence and conditions of salam contract along with the related issues within (article 380 article 387) 8 articles.

Basically, salam is one kind of sale. Thus, similar to any other sale contract, in salam also the ownership is transferred in return for a counter value. In an exchange contract, the asset could be either present or absent in the contracting session. Also, it could be established under the liability with detailed description and that is the subject matter of the salam sale. ${ }^{5}$

It is worthwhile to mention here that in the salam contract the buyer is known as "rabb al-salam", or "al-muslim", the seller is named as "al-muslam ilayh $\vec{\imath}$ ', the subject matter is known as "al-muslam fih $\vec{\imath}$ ' and the price is named as "ra's mâl al-salam". This paper makes a juristic evaluation of the articles of the Mejelle related to the salam sale.

As mentioned earlier, the Mejelle had been drafted based on the Hanafi School of law only. Generally, people who follow other Schools of Islamic law are reluctant to rely on the Mejelle while they are interested to know the opinion of other Schools on the articles of the Mejelle. Hence, due to the significance and present-day applications, this effort is made to make a juristic investigation and evaluation of the articles of the Mejelle on salam contract.

\section{METHODOLOGY}

This is a qualitative study and a method of content analysis is used to accomplish this study. The study is carried out based on the profound induction in the classical and contemporary literature of Islamic jurisprudence.

The study analyzes the articles of the Mejelle on salam contract and evaluates them along with other classical sources of different Schools of Islamic law, as well as with other contemporary literature written on modern Islamic banking operations.

Actually, the study investigates the articles of the Mejelle on salam contract making a comparison with the stands of various Schools of Islamic law. In this regard, the study follows the research methodology of Islamic Jurisprudence,

5 Ibn Rushd, Abū al-Wal̄̄d Muḥammad ibn Aḥmad, al-Muqaddimāt al-Mumahhidāt, vol. 2 (Bayrūt: Dār al-Gharb al-Islāmī, 1988), 19. 
i.e. discussion of the sources, comparison among the evidences and then giving preference to the opinion relies on the strongest evidence.

Finally, the study demonstrates some contemporary applications which are pertinent to the articles of the Mejelle on salam contract as an evidence on the relevance of the Mejelle to the present-day context.

\section{JURISTIC EVALUATION OF ARTICLES OF THE MEJELLE ON SALAM}

\section{Definition of Salam}

Lexically, salam gives the meaning of giving, providing credit, lending and others. The word "salam" is widespread to the people of Hijāz whereas the word "salaf" is common to the people of Iraq and both of them refer to the same contract. ${ }^{6}$ Salam is a form of sale in which the payment is settled in advance while the seller undertakes to supply some specific goods at a future date. It is named salam, derived from taslim which indicates the essence of this contract, and that is "taslim ra's al-māl", i.e. paying the capital in advance.

The article (123) of the Mejelle defines salam as, "A sale by immediate payment against future delivery." 8 The article (380) of the Mejelle further explains, "The contract of salam is like the sale which is concluded by offer and acceptance. So, if the purchaser says: "I have paid you one thousand dollars immediately against one hundred kilos of wheat which would be delivered in future, " and the seller agrees, then the contract of salam is concluded." 9

According to the Hanafi School, salam is, "the purchase of something on credit ( $\bar{a} j i l)$ in exchange for something in advance ( 'ájil)." ${ }^{10}$ So, "ajjil" refers to the commodity of salam (muslam fihi) which is delivered in future and " ajjil"

$6 \quad$ Al-Sharbīn̄i, Shams al-Dīn Muhammad Ibn al-Khațīb, Mughnī al-Muḥtāj ilā Ma 'rifat Ma 'ānī Alfāa al-Minhāj, vol. 3 (Qāhirah: Dār al-Ḥadìth, 2006), 5.

7 Ibn 'Ābidīn, Muhammad Amīn, Radd al-Muḥtār 'alā al-Durr al-Mukhtār, vol. 7 (Bayrūt: Dār Iḥyā' al-Turāth al-'Arabī, 1998), 347; Ibn Nujaym, al-Baḥr al-Rā'iq Sharh Kanz al-Daqā’ ’q, vol. 6 (Bayrūt: Dār al-Kutub al-'Ilmiyyah, 1997), 258.

8 Al-Majallah (Bayrūt: al-Mațba'ah al-Adabiyyah, 1302H), 35.

9 Al-Majallah, 66.

10 Ibn 'Ābidīn, Radd al-Muḥtār, vol. 7, 348; al-'Aynī, Badr al-Dīn, al-Bināyah Sharh al-Hidāyah, vol. 8 (Bayrūt: Dār al-Kutub al-'Ilmiyyah, 2000), 327; Ibn Nujaym, al-Bahrr al-Rā'iq, vol. 6, 258; Kamāl Ibn al-Humām, Sharḥ Fath al-Qadīr, vol. 7 (Bayrūt: Dār al-Kutub al-'Ilmiyyah, 1995), 66; Al-Fatāwā al-Hindiyyah fì Madhhāb al-Hanafiyyah, vol. 3 (Bayrūt: Dār al-Fikr, 2010), 171. 
refers to the capital of salam ( $r a$ 's mâl al-salam) which is paid in advance. The Hanafi School stipulates that for the validity of salam, the capital must be delivered in the contracting session, and the commodity must be on credit, so that there is no salam on spot.

The Mālikī School does not permit salam contract with immediate delivery. Also, they do not stipulate that the delivery of the price should be in the contracting session; rather they allow deferment of the price for two or three days. Hence, they define it as "a sale in which the payment is made in advance and the delivery of the commodity is deferred until the duration specified." 11 Al-Hattāa bays, salam is an exchange contract of the good which is liable on the seller with something that is neither a tangible asset nor a benefit. In salam contract both subject matters shall not be deferred as it becomes the same as the sale of debt with debt. ${ }^{12}$

The Shāfi' $\overline{1}$ School stipulates that for the validity of salam, the capital must be delivered in the session while the commodity can be deferred or can be immediately delivered. ${ }^{13}$ So, they define salam contract as a contract which is concluded on something what the seller is liable to deliver in exchange for a price that is immediately settled. ${ }^{14}$ Thus, this School opines, as salam contract is permissible with the deferred delivery of the commodity, it is also permissible in which the commodity is delivered immediately. ${ }^{15}$

The Hanbalī School agrees with the Hanafì School, and thus it defines salam as "the contract which is concluded on something deferred and described in the liability, against the price which shall be settled in the contracting session."16 In another words, "Making the delivery of return (price) immediately in return for another return (goods) defined in the liability until a period." 17

11 Aḥmad Ibn 'Arafah al-Dussūqī, Hāshiyah al-Dussūqī 'alā al-Sharh al-Kabīr, vol. 4 (Bayrūt: Dār al-Kutub al-'Ilmiyyah, 2003), 315.

12 Al-Ḥațāō, Abū 'Abd Allāh Muḥammad, Mawāḥib al-Jalīl li Sharh Mukhtaṣar Khalīl, vol. 6 (Bayrūt: Dār al-Kutub al-'Ilmiyyah, 1995), 476.

13 Al-Māwardī, Abū al-Hasan, al-Hāwī al-Kabīr fì Fiqh Madhhab al-Imām alShäfi 'ì, vol. 5 (Bayrūt: Dār al-Kutub al-'Ilmiyyah, 1999), 389.

14 Al-Nawawī, Yaḥyā Ibn Sharf al-Dīn, Rawdah al-Tālibīn, vol. 3 (Qāhirah: alMaktabah al-Tawfiqiyyah, 2000), 245; al-Sharbīnī, Mughnī al-Muhtāj, vol. 3, 5.

15 Ministry of Awqāf and Islamic Affairs, al-Mawsū'ah al-Fiqhiyyah, vol. 25 (Kuwait: Ministry of Awqāf and Islamic Affairs, 1992), 191.

16 Al-Bahūtī, Manșūr, Kashf al-Qinā' 'an Matn al-Iqnā', vol. 3 (Bayrūt: Dār alKutub al-'Ilmiyyah, 1997), 336; al-Mardāwī, 'Alā al-Dīn, al-Inșāffi Ma'rifat alRājị̆ min al-Khilāf 'alā Madhhab al-Imām Ahmad ibn Hanbal, vol. 5 (Bayrūt: Dār al-Kutub al-'Ilmiyyah, 1997), 71.

17 Ibn Qudāmah, Abī Muḥammad 'Abd Allāh Ibn Aḥmad Ibn Muhammad al- 
As discussed above, unlike the Shafi'i School, majority of the Schools of Islamic law define salam as a sale by immediate payment against future delivery of the commodity. The authors prefer the stand of majority as it reflects the essence of salam which has been legalized to facilitate an advance payment in exchange for a future delivery of the commodity after it becomes available. Nevertheless, in the definition of salam contract, the stand of articles of the Mejelle is in line with that of the majority Schools of Islamic law.

\section{The Evidence of Salam Sale}

According to all prominent Schools of Islamic law, the salam sale is valid and permissible. ${ }^{18}$ The validity of the salam sale is verified by the Qur' $\bar{a} n$, Sunnah, the consensus of the Muslim jurists and by an analogy. Allah SWT says:

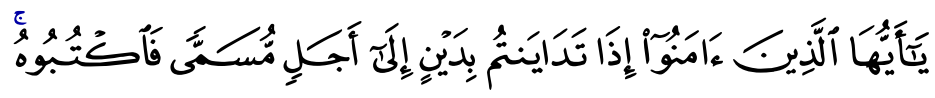

"O ye who believe! When you contract a debt for a fixed term, record it in writing."

(Surah al-Baqarah, 2: 282)

This verse is the evidence on the legality of salam sale. ${ }^{19}$ Reciting this verse, Ibn 'Abbās said: "I assure that Allah SWT has permitted the advance payment in this verse." ${ }^{20}$ Also, this verse validated the debt, and salam sale is one form of debt. The debt refers to each transaction where one consideration is on spot and another consideration is on credit. Everything that is present is

Maqdisī, al-Mughnī al-Sharh al-Kabīr, vol. 5 (Qāhirah: Dār al-Ḥadīth, 2004), 642.

18 Al-Marghīnānī, al-Hidāyah with al-Bināyah, vol. 8 (Bayrūt: Dār al-Kutub al'Ilmiyyah, 2000), 328; al-Ḥațāāb, Mawāhib al-Jalīl, vol. 6, 476; Ibn Rushd, Muḥammad ibn Aḥmad ibn Muḥammad, Bidāyah al-Mujtahid, vol. 2 (Bayrūt: Dār al-Kutub al-'Ilmiyyah, 2003), 311; al-Shīrāzī, Abū Isḥāq, al-Muhadhdhab fi Fiqh al-Imām al-Shāfi 'ī, vol. 2 (Bayrūt: Dār al-Kutub al-'Ilmiyyah, 1995), 71; al-Māwardī, al-Hēāwì al-Kabìr, vol. 5, 389; Ibn Qudāmah, al-Mughn̄̄, vol. 5, 642; al-Buhūtī, Kashf al-Qinā', vol. 3, 336; Ibn al-Humām, Sharḥ Fath al-Qadīr, vol. 7, 66 .

19 Al-Marghīnānī, al-Hidāyah with al-Bināyah, vol. 8, 328; al-Shīrāzī, alMuhadhdhab, vol. 2, 71; al-Māwardī, al-Hāài al-Kabìr, vol. 5, 388; al-Buhūtī, Kashfal-Qinā', vol. 3, 336; Ibn Nujaym, al-Bahr al-Rà' 'iq, vol. 6, 259; al-Sharbīnī, Mughnī al-Muḥtāj, vol. 3, 5; Ibn al-Humām, Sharḥ Fatḥ al-Qadīr, vol. 7, 66.

20 Al-Marghīnānī, al-Hidāyah with al-Bināyah, vol. 8, 328; al-Shīrāzī, alMuhadhdhab, vol. 2, 71; al-Māwardī, al-Hāwī al-Kabìr, vol. 5, 388; Ibn Qudāmah, al-Mughnī, vol. 5, 642; Ibn Nujaym, al-Bahrr al-Rā'iq, vol. 6, 259. 
called 'ayn and what is not present is called dayn (debt). ${ }^{21}$ Also, salam sale is validated by the verse which says:

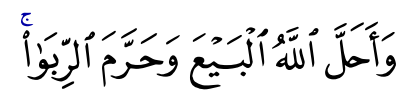

"Allah has permitted the sale."

(Surah al-Baqarah, 2: 275)

This encompasses all forms of sale except which are proven otherwise. Since salam is a form of sale, it is valid. ${ }^{22}$

With regard to the Sunnah:

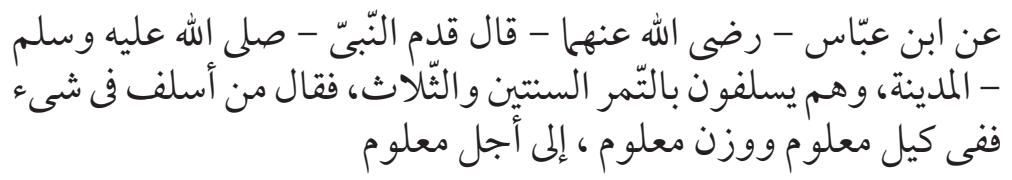

"Reported on the authority of Ibn 'Abbās RA, when the Prophet (pbuh) came to Madinah people used to sell the dates with advance payment for two or three years. Then the Prophet said: Whoever sells the dates with an advance payment must do it in a specified volume, and defined weights, for a known period of time." 23

This hadith has validated the salam sale since it is an exchange contract of deferred commodity with an immediate payment. ${ }^{24}$ Also, the validity of salam sale is inferred from another hadith whereby the Prophet (pbuh) forbade the sale of something which is not available to the seller and permitted the salam sale. $^{25}$

${ }_{21}$ Ibn al-'Arabī, Abū Bakr Muhammad ibn 'Abd Allāh, Aḥkām al-Qur'ān, vol. 1 (Bayrūt: Dār al-Kutub al-'Ilmiyyah, 1996), 327.

22 Al-Ḥațāā, Mawāhib al-Jalīl, vol. 6, 476.

23 Al-Bukhārī, Șaḥ̄h al-Bukhārī, vol. 2 (Bayrūt: Dār al-Kutub al-'Ilmiyyah, 2002), 52, "Bāb al-salam ilā ajal ma'lūm," hadìth no. 2253.

24 Ibn Rushd, Bidāyah al-Mujtahid, vol. 2, 311; al-Hatțāb, Mawāhib al-Jalīl, vol. 6, 476; Ibn Qudāmah, al-Mughnī, vol. 5, 642; al-Buhūtī, Kashf al-Qinā', vol. 3, 336; al-Sharbīnī, Mughnī al-Muhtāj, vol. 3, 5.

25 Al-Marghīnānī, al-Hidāyah with al-Bināyah, vol. 8, 329; Ibn al-Humām, Sharh Fath al-Qadīr, vol. 7, 67; al-Zayla‘̄i, Jamāl al-Dīn Abū Muhammad, Nașb alRāyah li Ahāāìth al-Hidāyah, Bāb Khiyār al-Ru'iayh, vol. 4 (Bayrūt: al-Maktab al-Islāmī, 1393 AH), 45. 
In addition, the salam sale is validated by the unanimous agreement of the Muslim jurists. ${ }^{26}$ Actually, salam sale is permitted considering need of the people and removing harm from them. The farmer, for example, might not have enough funds to look after the land and cultivation till the harvest. Also, he might not get someone who is willing to lend him the necessary funds. Thus, he needs a type of transaction that enables him to manage the necessary funds to continue the plowing and cultivation, otherwise he would be in trouble and hardship. In this light, the salam contract is made valid and lawful. ${ }^{27}$ However, it is mentionable that the reasoning does not allow the salam sale as it is the sale of what is not in existence. Despite this the analogy is overlooked due to the hadith that has been mentioned above. ${ }^{28}$

\section{The Conclusion of Salam Sale}

The salam sale is concluded with the offer and acceptance. Muslim jurists agree upon that the offer is valid by the word salam or salaf, and any word deriving from them since both denote the same sense. For the acceptance, any expression that indicates the consent suffices, such as "I have accepted", "I agreed" and the like. Thus, article (380) of the Mejelle states:

"The contract of salam is like the sale which is concluded by offer and acceptance. So, if the purchaser says: 'I have paid you $\$ 100$ immediately against $100 \mathrm{~kg}$ of wheat which would be delivered in future (using the word salam)', and the seller agrees, then the contract of salam is concluded." 29

However, there is dispute among the scholars as to whether salam sale is concluded with the word al-bay ' or not. This dispute is discussed as follows:

The Hanafi School opines that salam sale is concluded with the word albay ' as well as with any expression derived from it. This is because salam is a form of sale, due to which it is valid with the word al-bay ' as long as the intention of salam is obvious and the respective conditions are fulfilled. ${ }^{30} \mathrm{In}$

26 Al-Ḥațāā, Mawāhib al-Jalīl, vol. 6, 476; Ibn Qudāmah, al-Mughn̄̄, vol. 5, 642; Ibn Nujaym, al-Bahr al-Rā'iq, vol. 6, 259.

27 Ibn Qudāmah, al-Mughnī, vol. 5, 643; al-Buhūtī, Kashf al-Qinā', vol. 3, 336.

28 Al-Marghīnānī, al-Hidāyah with al-Bināyah, vol. 8, 329; Ibn al-Humām, Sharh Fath al-Qadìr, vol. 7, 67.

29 Al-Majallah, 66.

30 Al-'Ayn̄̄, al-Bināyah Sharh al-Hidāyah, vol. 8, 328; Ibn 'Ābidīn, Radd alMuhtā̄r, vol. 7, 348; Ibn al-Humām, Sharh Fath al-Qadīr, vol. 7, 66; al-Fatāwā al-Hindiyyah fì Madhhāb al-Hanafiyyah, vol. 3, 171. 
the hadith, the contract of salam has been deemed a form of sale because the Prophet (pbuh) forbade the sale of something which is not possessed and permitted the salam as an exception. ${ }^{31}$ Thus, salam sale is an exception from the ordinary sale. Although salam is the sale of something which is not possessed, it is made permissible. ${ }^{32}$

According to the Mālikī School, salam sale is concluded with the word albay ' and any expression derived from it, since it is a sale contract in substance. ${ }^{33}$

The Shāfi' $\overline{1}$ School has two opinions in this respect. One is that the salam sale is concluded with the word $a l-b a y$ ' as it is one kind of sale. Second is that even though salam is a form of sale, it is not ordinary but rather an exclusive form of sale, and thus it is not concluded with the word al-bay'. It should be confined to the word salam, without exceeding to any other word. ${ }^{34}$

According to the Hanbali School, the salam sale is concluded with the word salam, salaf, bay ' and every expression through which the sale is concluded. ${ }^{35}$ Ibn Taymiyyah says that this is a general principle that as long as the intention of contracting parties becomes clear to each other, the contract is concluded accordingly. Thus, with any word which makes the respective purpose evident, salam sale is concluded with that. ${ }^{36}$

Nonetheless, the authors prefer that the salam contract be concluded with the word salam or any word from the same root, which denotes what the contracting parties intend to perform such an arrangement. In substance, salam is a sale contract though it is named as salam exclusively. In addition, concerning the dealings and transactions, the substance is considered, not their forms, as far the Islamic legal maxim is concerned.

It is notable to mention that the article (380) of the Mejelle conforms to the views of all the prominent Schools of Islamic law that "the salam sale is concluded with the word al-bay ' and/or any expression derived from it".

\footnotetext{
31 Al-Zayla'īi, Naṣb al-Rāyah li Aḥ̂̄dìth al-Hidāyah, vol. 4, 45.

32 Al-Kāsān̄̄, 'Alā' al-Dīn Abū Bakr, Badā 'i ' al-Șanā' ' ' fi Tart̄̄b al-Sharā'i ', vol. 7 (Qāhirah: Dār al-Hadīth, 2005), 88.

33 Aḥmad Ibn 'Arafah al-Dussūqūe Hāshiyah al-Dussūqū 'alā al-Sharḥ al-Kabīr, vol. 4, 315 .

34 Al-Māwardī, al-Hāwwì al-Kabìr, vol. 5, 389.

35 Al-Buhūtī, Kashf al-Qinā', vol. 3, 336.

36 Ibn Taymiyyah, Majmū 'ah al-Fatāwā, vol. 20 (Miṣr: Dār al-Wafā', 1997), 533.
} 


\section{The Items in Which Salam Sale is Applicable}

Salam is not applicable to all the items and it is subject to certain conditions. All the Schools of Islamic law agree upon that the salam is valid in the things which are measured by volume or weight. On the other hand, all jurists agree that in the things which are not established in the liability, salam is not valid for them, such as the houses and real properties. In the case of performing salam in animals, scholars differ in opinion. The Māliki, Shāfi '‘̄ and reliable stand of Hanbalī School validate this whereas the Hanafī School invalidates. ${ }^{37}$

In this respect, the articles (381-385) of the Mejelle state, "salam sale is valid only in the things that can be determined by amount and attribute, like the highest and lowest. Things that are measured by volume, weight, length and magnitude would be determined by volume, weight and the yard. Things that are estimated by enumeration, and which closely resemble each other, may be measured by counting, and by the volume and weight as well. Nevertheless, in the case of things that are measured by counting, like burnt bricks and sun-dried bricks, the mold thereof should be made known as well. Moreover, things that are measured by length, their length, breadth and thickness must be specified. Also, the material they are made from, and the place in which they were made, must be mentioned." ${ }^{38}$ So, according to the articles, the salam arrangement is applicable only to the items which would be specified either by amount or attribute.

Hanafi School opines that the salam contract is valid in those things which are measured by volume and weight, except the dirham and dinar. Since these are considered the price, salam is not valid there because the subject matter of salam should be something which would be against the price. Also, salam is valid in those things that are measured by counting and which closely resemble each other like the nuts, eggs and so forth. Since things that are countable and close to each other are specified by description, and are deliverable and defined, salam is valid there. Moreover, here the small and big are equal as there is little difference which is usually ignored in the custom of the people. But, if something in which the difference of one from another is excessive, like watermelon, pomegranate and so on, the salam contract is not valid there. Thus, according to this School, salam in animals is not valid because these are not measured by volume, weight, counting and the like. ${ }^{39}$

37 Ibn Rushd, Bidāyah al-Mujtahid, vol. 2, 312.

38 Al-Majallah, 66.

39 Al-Marghīnān̄̄, al-Hidāyah with al-Bināyah, vol. 8, 330; Ibn 'Ābid̄̄n, Radd alMuḥtār, vol. 7, 348; Ibn Nujaym, al-Baḥr al-Rā'iq, vol. 6, 259; Ibn al-Humām, Sharh Fatḥ al-Qadīr, vol. 7, 68; al-Fatāwā al-Hindiyyah fì Madhhāb alHanafiyyah, vol. 3, 173. 
Mālikī School opines that salam is valid in the items which are measured by volume and weight. The animals can also be the subject matter of salam sale. However, in things which are not established in the liability, like houses and real assets, salam is not permissible there. The salam arrangement is also permissible in the utility of the things specified like the dwelling of house, riding of animal, service of the slave, and so forth. ${ }^{40}$

According to the Shāfi' $\overline{1}$ School, salam is valid in everything which is eligible to be the subject matter of the sale. Also it is permissible in everything which can be specified by amount and attribute, as well as measured by volume, weight, counting and yard. So, fruits, seeds, cloths, animals, slaves, timbers, stones, iron, lead, glasses, etc. can be the subject matter of the salam contract. ${ }^{41}$

According to the Hanbali School, salam sale is valid in the items which are measured by volume and weight. Also, in something which can be determined by any measurement, salam is permissible there. Moreover, salam is valid in the countable items which are not different from each other excessively. Likewise, salam is permissible in the animals as well, as far as the reliable stand of this School is concerned. ${ }^{42}$

As mentioned above, all agree that the salam is valid in the items which are measured by volume, weight, counting, yard and so forth. Also, salam is permissible in the things which can be determined by attributes and specifications. However, the scholars dispute in the case of animals whereby the majority opines that salam in animals is permissible and the Hanafî School opines that it is not permissible.

The Hanafī School argues using the hadìth which says that:

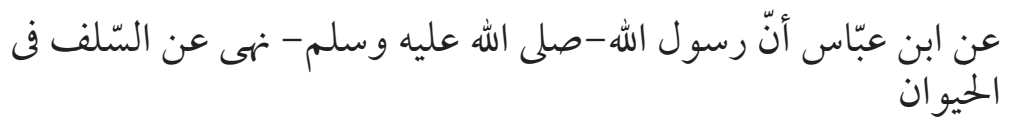

40 Ibn Rushd, Bidāyah al-Mujtahid, vol. 2, 312; al-Dussūqī, Hāshiyah al-Dussūqū, vol. 4, 317; al-Ḥaț̣āb, Mawāhib al-Jalīl, vol. 6, 480; al-Kharshī, Muhammad ibn 'Abd Allāh, Sharh al-Kharshī 'alā Mukhtaṣar Khalīl, vol. 6 (Bayrūt: Dār al-Kutub al-'Ilmiyyah, 1997), 63.

41 Al-Shīrāzī, al-Muhadhdhab, vol. 2, 72; al-Māwardī, al-Hāwī al-Kabīr, vol. 5, 399; al-Qalīyūbī wa 'Amīrah, Shihāb al-Dīn, Hāshiyat al-Qalīyūbī wa 'Amīrah, vol. 2 (Bayrūt: Dār al-Kutub al-'Ilmiyyah, 2003), 396; al-Nawawī, Rawḍh al-Ṭālibīn, vol. 3, 258; al-Sharbīnī, Mughnī al-Muhtāj, vol. 3, 18; al-Shāfi‘̄i, al-Umm, vol. 4, 70.

42 Ibn Qudāmah, al-Mughnī, vol. 5, 646; al-Buhūtī, Kashf al-Qinā', vol. 3, 337; alMardāwī, al-Inșāf, vol. 5, 72 . 


\section{"Reported on the authority of Ibn 'Abbās RA, the Prophet (pbuh) forbade doing salam in animals." 43}

So it encompasses all types of animals, even the sparrows. ${ }^{44}$ However, the majority says that this hadith is very weak and not eligible to establish the argument. $^{45}$

On the other hand, the validity of the salam in animals is inferred from the hadith narrated by Ibn 'Umar which says that the Prophet (pbuh) ordered him to prepare the camels for the army, but camels that were available did not suffice for them. Then the Prophet instructed him to take from the animals of the charity. Thereafter the camels were taken from the charity fund provided that two camels will be returned for the one. ${ }^{46}$ Also, as reported that the Prophet performed salam contract in the animals. ${ }^{47}$ So, such narrations indicate that the animals can be specified and established in the liability. ${ }^{48}$

Furthermore, the reason for this disagreement among the scholars is the conflict of the narrations in this issue. In addition, scholars also differ in the view on whether the animals can be determined and defined by attributes or not. Those who think that they are identical in creation and can be defined by attributes are with the opinion of validity of the salam in animals. However, those who think they are dissimilar in creation and cannot be determined by specifications are with the opinion of invalidity of the salam in animals. ${ }^{49}$

Hereby the authors prefer the stand of the validity of salam sale in animals. Though the animals are dissimilar in nature and in creation, they can be defined by specifications and determined with the attributes. Nevertheless, there is no article in the Mejelle on the issue of the legality of salam sale in animals. Thus, the authors suggest an article or articles could be provided in the Mejelle resolving the issue of the validity of salam contract in animals.

43 Al-Dār Quṭn̄̄, Sunan al-Dār Quṭn̄, vol. 2/3 (Bayrūt: Dār al-Kutub al-'Ilmiyyah, 2003), 60, "Kitāb al-Buyū'," hadīth no. 3040.

44 Al-Marghīnānī, al-Hidāyah with al-Bināyah, vol. 8, 335.

45 Ibn Rushd, Bidāyah al-Mujtahid, vol. 2, 312.

46 Al-Dār Quṭnī, Sunan al-Dār Quṭnī, vol. 2/3, 58, "Kitāb al-Buyū'," hadīth no: 3035 .

47 Ibn Ānas, Mālik, al-Muwațtā'; vol. 2 (Morocco: Dār al-Āfāq al-Jadīdah, 1998), 205, "Kitāb al-Buyū', Bāb Mā Yajūzu min al-Salaf", hadīth no. 93.

48 Ibn Rushd, Bidāyah al-Mujtahid, vol. 2, 312; al-Shīrāzī, al-Muhadhdhab, vol. 2, 72; al-Māwardī, al-Hāwī al-Kabīr, vol. 5, 399.

49 Ibn Rushd, Bidāyah al-Mujtahid, vol. 2, 313. 
Nevertheless, the related articles conform to the views of all the prominent Schools of Islamic law that "salam sale is valid in the things which can be determined by amount and attribute". So, all concur that "the items which are measured by volume, weight, yard, and counting, could be the subject matter of a salam sale".

\section{The Condition for the Validity of the Salam}

Apparently salam is the sale of something which is not in existence and is legalized as an exception from the general requirements of the sale contract in Islamic law. However, the validity of the salam sale is subject to some conditions which are discussed in the articles of the Mejelle, as follows:

\section{Condition related to the Subject Matter of the Salam}

The article (386) of the Mejelle states, "It is essential for the validity of salam sale that the genus of the thing sold should be specified; for example, corn, rice or dates. Also, the particular type of the subject matter, such as whether produced by rain or by irrigation; the quality, for example, the highest or the lowest; the volume of the price and the thing sold; as well as the time and place of delivery thereof should be mentioned." 50

However, it is not mandatory to define all the attributes, as it is not possible and it might lead to the impossibility to deliver the subject matter. Hence, it is enough to define only the apparent and desired attributes that are important and mostly lead to the change in the price. ${ }^{51}$

According to the Hanafi School, the subject matter of salam should be known precisely by attributes and whether deliverable. Also, it should be available throughout the duration between the contract and the delivery. The Prophet says:

$$
\text { لا تسلفوا فى النّخل حتّى يبدو صالحهه }
$$

"Do not perform salam in the fruits until their goodness appears." 52

50 Al-Majallah, 66.

51 Ibn Qudāmah, al-Mughnī al-Sharḥ al-Kabīr, vol. 5, 648; al-Kharshī, Muḥammad ibn 'Abd Allāh, Sharh al-Kharshī 'alā Mukhtașar Khalīl, vol. 6, 83.

52 Al-Sajistān̄̄, Sulaymān Ibn al-Ash'ath, Sunan Abī Dāwud, vol. 3 (Bayrūt: Dār Ibn Ḥazm, 1997), 479, "Bāb fi al-salam fī thamarat bi 'aynihā”, hadìth no. 3467. 
Also, it would be deliverable by collection and thus must be available throughout the duration for the one to be able to collect it. ${ }^{53}$ Also, the time and place of the delivery of the subject matter shall be specified. In fact, as far as the Hanafī School is concerned, there are seven things which must be known and specified for validity of the salam sale. These are the genus, type, attribute, amount, duration, amount of the capital and finally the place of delivery of the commodity, which must be known and specified upon conclusion of the salam sale. However, the two disciples of Imam Abū Haniffah opine that it is mandatory neither to mention the capital if specified, nor to name the place of delivery and it would be delivered at the contracting place. ${ }^{54}$

According to the Mālikī School, there is no dispute if the subject matter of salam is something which is measured by amount then it must be specified either by volume or weight or counting or the like. If the subject matter is something which is determined by attributes then it must be specified by attributes that are desired in the contract. ${ }^{55}$ Regarding the duration, like the Hanafi School, this School also stipulates that the duration shall be deferred and specified. ${ }^{56}$ Unlike the Hanafi School, this School opines that it is not mandatory that the subject matter of salam shall be available upon the contract. Also, the place of the delivery of salam commodity is not necessarily be specified. ${ }^{57}$ Moreover, the subject matter of salam should be the debt which is defined in the liability. ${ }^{58}$

The Shāfi'i School agrees with others that salam commodity must be known by volume, weight, counting, yard and the like. ${ }^{59}$ The salam commodity

53 Al-Marghīnānī, al-Hidāyah with al-Bināyah, vol. 8, 338; Ibn Nujaym, al-Baḥr alRā'iq, vol. 6, 266; Ibn al-Humām, Sharḥ Fatḥ al-Qadīr, vol. 7, 78.

54 Al-Marghīnānī, al-Hidāyah with al-Bināyah, vol. 8, 346; Ibn 'Ābidīn, Radd alMuhtār, vol. 7, 355; Al-Kāsānī, Badā'i ' al-Ṣanā'i', vol. 7, 103; Ibn Nujaym, alBậr al-Rā'iq, vol. 6, 269; Ibn al-Humām, Sharh Fatḥ al-Qadīr, vol. 7, 83; alFatāwā al-Hindiyyah, vol. 3, 172.

55 Ibn Rushd, Bidāyah al-Mujtahid, vol. 2, 313; al-Dussūqī, Hāshiyah al-Dussūqū, vol. 4, 325; al-Qarāfì, Shihāb al-Dīn, al-Dhakhīrah fi Furū' al-Mālikiyyah, vol. 4 (Bayrūt: Dār al-Kutub al-'Ilmiyyah, 2001), 436; al-Kharshī, Muhammad ibn 'Abd Allāh, Sharḥ al-Kharshī 'alā Mukhtașar Khalīl, vol. 6, 83.

56 Al-Hatțāa, Mawāhib al-Jalīl, vol. 6, 499; Ibn Rushd, Bidāyah al-Mujtahid, vol. 2, 314; al-Qarāfī, al-Dhakhīrah, vol. 4, 446; al-Kharshī, Muhammad ibn 'Abd Allāh, Sharh al-Kharshī 'alā Mukhtașar Khalīl, vol. 6, 77.

57 Ibn Rushd, Bidāyah al-Mujtahid, vol. 2, 315; al-Qarāfī, al-Dhakhīrah, vol. 4, 472.

58 Al-Kharshī, Muḥammad ibn 'Abd Allāh, Sharḥ al-Kharshī 'alā Mukhtașar Khalīl, vol. 6,91 .

59 Al-Shīrāzī, al-Muhadhdhab, vol. 2, 72; al-Qalīyūbī, Hāashiyat Qalīyūbī, vol. 2, 396; al-Nawawī, Rawḍh al-Ṭālibīn, vol. 3, 255; al-Sharbīnī, Mughnī al-Muḥtāj, vol. 3, 12 . 
must also be precise with the attributes that are desired and make the price fluctuates. ${ }^{60}$ Also, the subject matter should be deliverable upon the maturity of the contract and is not required to be available upon the contract. ${ }^{61}$ Regarding the duration, if it is deferred then it must be known. However, salam contract is also valid if it is concluded on spot, as far as the Shāfi ' $\overline{1}$ School is concerned. ${ }^{62}$ In respect of the place of delivery, in general salam contract is permissible without determining the place of delivery. However, if making the delivery incurs the cost, or in a place which is unusual like the desert and so on, then it must be specified upon the contract. ${ }^{63}$

The Hanbalī School also agrees with other Schools that the salam commodity should be known and specified in terms of the genus, amount, attribute, duration and the like. If the commodity is something which is measured or weighed then the volume, weight, amount, yard, etc. should be known accordingly. ${ }^{64}$ If the subject matter is something which is determined by attributes that make the price fluctuates, then such attributes must be known and specified. ${ }^{65}$ With regard to the duration, it should be deferred and known. According to this School, the salam contract with immediate delivery is not permissible. ${ }^{66}$ Furthermore, the salam commodity must be available and deliverable upon maturity and it is not required to be available upon or throughout the contract period. ${ }^{67}$ Another important condition is that the salam commodity should be the debt defined in the liability, and if it is the physical asset then salam contract is invalid. ${ }^{68}$ Regarding the place of the delivery,

60 Al-Shīrāzī, al-Muhadhdhab, vol. 2, 75; al-Nawawī, Rawḍh al-Ṭālibīn, vol. 3, 256; al-Sharbīnī, Mughnī al-Muḥtāj, vol. 3, 15.

${ }^{61}$ Al-Qalīyūbī, Hāashiyat Qalīyūbī, vol. 2, 394; al-Sharbīnī, Mughnī al-Muhtāj, vol. 3,11 .

62 Al-Qalīyūbī, Hāshiyat Qalīyūbī, vol. 2, 393; al-Shīrāzī, al-Muhadhdhab, vol. 2, 76; al-Nawawī, Rawḍh al-Ṭālibīn, vol. 3, 248; al-Sharbīnī, Mughnī al-Muhtāàj, vol. 3,9 .

63 Al-Qalīyūbī, Hāashiyat Qalīyūbī, vol. 2, 392; al-Shīrāzī, al-Muhadhdhab, vol. 2, 77; al-Sharbīnī, Mughnī al-Muḥtāj, vol. 3, 8.

${ }^{64}$ Ibn Qudāmah, al-Mughnī al-Sharh al-Kabìr, vol. 5, 658; al-Buhūtī, Kashf alQinā', vol. 3, 347; al-Mardāwī, al-Inșāf, vol. 5, 72.

65 Al-Buhūtī, Kashf al-Qinā', vol. 3, 340; Ibn Qudāmah, al-Mughn̄̄, vol. 5, 648.

${ }^{66}$ Ibn Qudāmah, al-Mughnī, vol. 5, 662; al-Buhūtī, Kashf al-Qinā', vol. 3, 349; alMardāwī, al-Inșāff, vol. 5, 85.

67 Al-Buhūtī, Kashf al-Qinā', vol. 3, 354; Ibn Qudāmah, al-Mughnī, vol. 5, 668; alMardāwī, al-Inșāf, vol. 5, 90.

68 Ibn Qudāmah, al-Mughn̄̄ al-Sharh al-Kabīr, vol. 5, 677; al-Buhūtī, Kashf alQinā', vol. 3, 357; al-Mardāwī, al-Inșāf, vol. 5, 93. 
it is not mandatory to mention the place of delivery since it will usually be delivered in the contract place. However, if it is not possible to make delivery in the contract location then the place of delivery must be determined and agreed upon. ${ }^{69}$

So, in the issue of the conditions of salam commodity, it is found that all the Schools agree upon that the salam commodity should be known and specified by volume, weight, counting, yard and the like, pursuant to the nature of the commodity. Also, all agree that the commodity should be specified with the attributes, particularly when the attributes lead to the price fluctuation. Regarding the duration, the majority opines that it should be deferred and known, except the Shäfi' $\overline{1}$ School who opines that salam is valid with the immediate delivery as well. In the issue of being available, unlike the majority, the Hanafĩ School opines that it should be available in the whole contract period until maturity whereas the majority opines that being available and deliverable upon maturity is adequate. Moreover, concerning the place of delivery, the Hanafi School opines that it should be determined upon the contract while the majority opines that if delivery incurs the cost or it is not possible to make delivery in the contract place, then it should be specified earlier, otherwise the contract place is determined as the place of delivery.

It should be noted that the related articles of the Mejelle which stipulate that "the salam commodity should be known and defined by volume, weight, counting, yard etc.", is considered to be the agreed upon view of all prominent four Schools of Islamic law. However, concerning the issue of being available, the majority opines that it is sufficient to be available upon maturity, whereas the Hanafi School opines that it should be available upon conclusion of the contract till the maturity. The authors prefer the stand of majority and opine that it is adequate to be deliverable upon maturity. Nevertheless, the respective article of the Mejelle has not resolved this issue. Also, there is no discussion in the articles on the condition of the debt as well as on the performance of salam contract with the immediate delivery. Hereby the authors suggest the required article(s) could be provided resolving the aforementioned issue and discussing the condition of the debt as well as the issue of salam contract with the spot delivery.

\section{Condition related to the Price of the Salam}

The article (387) of the Mejelle states, "It is essential for continuation of the validity of salam sale that the price should be settled in the meeting where

69 Al-Buhūtī, Kashf al-Qinā', vol. 3, 357; Ibn Qudāmah, al-Mughñ̄ al-Sharh alKabīr, vol. 5, 678; al-Mardāwī, al-Inșāff, vol. 5, 94. 
contract is concluded. If the contracting parties disperse before the settlement, the contract is revoked." 70

According to the Hanafi School, the salam is not valid until the price is possessed before dispersal of the contracting parties. If the price is in the form of currency, then the absence of the price makes it the sale of debt with debt, which is not permissible. If the price is in any other form except currency it is not then the salam contract. Since the salam is the exchange of something immediately settled with something deferred, the absence of the settlement causes to make it something other than the salam contract. ${ }^{71}$

According to the Mālikī School, the price of the salam contract should be paid fully in the contracting session. However, it could be delayed, but for not more than three days, with or without stipulation. ${ }^{72}$ The Shāfi' 1 School opines that the capital of salam must be settled and possessed in the contracting session, otherwise the salam is invalid. ${ }^{73}$ According to the Hanbali School, the possession of the capital of salam should be made in the contracting session. If the parties in the contract disperse before that, then the salam is invalid. ${ }^{74}$

Nevertheless, all the Schools agree that the settlement of the salam capital should not be deferred until a long period. However, according to the majority, the price of the salam should be settled before dispersal of the contracting parties. Since this is an exchange contract, the condition of deferment of the price is not permissible there, and accordingly the dispersal before settlement is impermissible. The Māliki School is with the view that the settlement of salam could be delayed up to not more than three days. Since deferment of three days or less is considered the immediate settlement it could be delayed up to that.

70 Al-Majallah, 66.

71 Al-Marghīnānī, al-Hidāyah with al-Bināyah, vol. 8, 353; al-Kāsān̄̄, Badā'i * al-Șanā' 'i', vol. 7, 92; Ibn Nujaym, al-Baḥr al-Rā'iq, vol. 6, 271; al-Fatāwā alHindiyyah, vol. 3, 171.

72 Al-Ḥațāāb, Mawāhib al-Jalīl, vol. 6, 476; Ibn Rushd, Bidāyah al-Mujtahid, vol. 2, 313; al-Dussūqī, Hāshiyah al-Dussūqū, vol. 4, 315; al-Qarāfī, al-Dhakhīrah, vol. 4, 425; al-Kharshī, Muḥammad ibn 'Abd Allāh, Sharḥ al-Kharshī 'alā Mukhtașar Khalīl, vol. 6, 62.

73 Al-Shīrāzī, al-Muhadhdhab, vol. 2, 78; al-Qalīyūbī, Hāshiyat Qalīyūbī, vol. 2, 389; al-Māwardī, al-Hāwwì al-Kabīr, vol. 5, 403; al-Nawawī, Rawdah al-Ṭālibìn, vol. 3, 245; al-Sharbīnī, Mughnī al-Muhtāj, vol. 3, 5.

74 Ibn Qudāmah, al-Mughnī al-Sharh al-Kabìr, vol. 5, 671; al-Buhūtī, Kashf alQinā', vol. 3, 355; al-Mardāwī, al-Inșāf, vol. 5, 91. 
Concerning this issue, the authors prefer the opinion of giving a grace of not more than three days for the settlement. This would ease the flow of transactions and eliminate the possible harm in this regard. Moreover, delaying up to three days does not contradict any fundamental tenet of Islamic law since the settlement within three days is almost as same as the settlement on spot. Nonetheless, in this issue, the article of the Mejelle conforms to the stand of the Majority Schools of Islamic law.

\section{CONTEMPORARY APPLICATIONS OF SALAM CONTRACT}

In the present world, the salam contract is being practiced widely in Islamic banks and Islamic financial intuitions. It has been used primarily to provide financing in the agricultural sector. An agricultural country like Sudan has a huge demand for the arrangements based on the salam contract. Some applications of the salam contract are as follows:

\section{Salam Financing in Modern Islamic Banking System}

Salam is made valid in the Islamic law to satisfy the necessity of farmers and traders. It provides financing facilities to the small farmers and traders. However, this mode of financing can be utilized by modern financial institutions to provide financing in all sectors, particularly the agriculture sector. It is needless to say that salam contract would be concluded on a lower rate compared to the price of those commodities when bought and delivered on the spot. Thus, the difference between two prices is considered a valid profit for the financial institutions.

In respect of the mode of payment of salam sale, the majority of jurists argue that payment must be made immediately upon conclusion of the contract, so that the arrangement does not convert to the sale of debt with debt, which is prohibited. In the banking system, however, payment in cash is not done and moreover it is not practical. The bank may credit the amount to the seller's account, or in the case of long-term financing, it may grant a line of credit. It may also issue a pay order in favor of the seller which may be cashable on demand. In all such cases money remains in the bank but is placed at the disposal of the seller.

Furthermore, in salam sale, since the delivery of commodity would be made in future, financial institutions may request the seller to provide a security, which can be a form of a guarantee or in the form of a mortgage, to cover the risk of non-delivery. In the case of default, the guarantor may be asked to deliver the same commodity. If there is a mortgage, the buyer or the financier 
may sell the mortgaged property and the sale proceeds can be used either to realize the required commodity by purchasing it from the market, or to recover the price advanced by him. ${ }^{75}$

\section{The Concept of Parallel Salam (Salam al-Muwāzi}

Another possible solution to lessen the risk of non-delivery or incomplete delivery of the salam commodities is by exercising the parallel contract of salam. After purchasing a commodity through salam, the bank may sell it through a parallel contract of salam for the same date of delivery.

In the parallel salam arrangement, the bank makes two different contracts. In the first one, the bank is the buyer while in the second one the bank is the seller. Obviously these two contracts must be independent from each other. They cannot be interrelated to each other in a way that the rights and obligations of one contract are dependent upon the rights and obligations of the parallel contract. The parallel salam is allowed with a third party only. The seller in the first contract cannot be made purchaser in the parallel contract of salam, because it will be tantamount to a buy-back agreement, which is not permissible in Shariah. Even if the purchaser in the second contract is a separate legal entity but is fully owned by the seller in the first contract, such an agreement is not allowed, as in practical terms it will amount to a buyback contract. For instance, A has purchased 1000 bags of wheat by way of salam from B, a joint stock company. B has a subsidiary $\mathrm{C}$, which is a separate legal entity but is fully owned by B. A cannot contract the parallel salam with C. However, if $\mathrm{C}$ is not wholly owned by $\mathrm{B}$, Then $\mathrm{A}$ can contract a parallel salam with it, even if some shareholders are common between $\mathrm{B}$ and $\mathrm{C} .{ }^{76}$ The Shariah Standard (10) of AAOIFI validates the parallel salam, whereby the standard says:

"It is permissible for the seller to enter into a separate, independent salam contract with a third party in order to acquire goods of a similar specification to those specified in the first salam contract, so that the first salam obligation will be discharged by delivering these goods. Hence, the seller in the first salam contract becomes the buyer in the second salam contract." 77

75 International Centre for Education in Islamic Finance, Sharī'ah Rules in Financial Transactions (Kuala Lumpur: INCEIF, 2011), 230-231.

76 Sharī'ah Rules in Financial Transactions, 233.

77 AAOIFI, Shari'ah Standard No. 10, salam and Parallel salam, 6/1 (Bahrain: Manama, 2010). 


\section{Issuing Șukūk based on the Salam Contract}

Using salam as an underlying contract, salam șukūk can be issued. Șukūk issuance that utilizes salam arrangement has become a popular structure in Bahrain. It has been used by the central bank of Bahrain as short-term Islamic liquidity instruments, with tenures ranging from 3 months to 9 months. The transaction normally involves a mudārabah investment followed by a purchase of commodities by using salam contract. Salam șukukk are issued to evidence the rights of the investors over salam receivables. The commodities will then be sold to the end-users for a profit. Nevertheless, the salam șukük are not tradable. ${ }^{78}$ The Shariah Standard (10) of AAOIFI states that it is not permitted to issue tradable bonds based on the debt from a salam contract. ${ }^{79}$

The ground of this impermissibility is that in this case the subject matter of salam contract is a debt and not any ascertained thing. While the articles (381385 ) of the Mejelle advocate, as mentioned above, the salam sale is valid only in the things that can be specified by amount and attribute. If salam contract is concluded on debt then it would be the sale of debt against debt which is not allowed. Also, the continuous existence of the stated șukuk in the market and the capacity of purchaser to deliver them upon maturity of the contract is something that cannot be assured. ${ }^{80}$

\section{Salam as an Alternative to Short Selling}

Nowadays salam contract may be used to structure an Islamic derivative instrument as an alternative to short selling. In the salam contact, the existence of the goods is not required upon entering the contract. An investor in stocks can hedge part of his exposure to cover the downside risk by selling the stock as salam. In the case of conventional short selling, there are two distinct transactions: borrowing of stock at interest and selling the stock. In salam, there is a sale but no borrowing of the stock. The sale price may incorporate the time value of money (financing cost) but early delivery of goods will not reduce the price as the full price is paid in advance. For short selling, dividend during the borrowing period belongs to the lender. In salam, it needs to be estimated and factored into the price. ${ }^{81}$

\footnotetext{
78 Securities Commission Malaysia, The Islamic Securities (Sukuk) Market (Kuala Lumpur: Securities Commission Malaysia, 2009), 64.

79 AAOIFI, Shari'ah Standard No. (10), Salam and Parallel Salam (7).

80 AAOIFI, Shari'ah Standard No. (21): Financial Paper (Shares and Bonds).

81 Khairi Saat, Mohamad, Understanding Islamic Capital Market (Kuala Lumpur: IBFIM, 2014), 348.
} 
The short selling structure with salam contract includes a concurrent cash sale and salam purchase of a stock. Under this arrangement, the owner sells his stocks to a short seller for cash. At the same time, the owner buys on salam the same amount of stocks from the short seller at an agreed price. AAOIFI's Shariah standard (21) does not allow the use of salam contract in shares on the ground that they are not autonomous rather they represent the company's assets. Since, a company's assets are changing; a seller cannot deliver the same stocks requested by the buyer. However, the Shariah Advisory Council of the Securities Commission Malaysia allow the use of salam in shares on the ground that shares are eligible to be the subject matter of salam contract as long as they are available in the market. In this context, the Regulated Short Selling (RSS) ensures that the shares are available in the market and can be delivered upon the time of delivery. ${ }^{82}$

\section{CONCLUSION}

Though the general principle says that the sale of something that is not possessed and not present is not permissible, the sale of salam is made valid as an exception from this, considering the need of the people. Salam is defined as the sale of something that is described and specified in the liability, subject to certain conditions. The related article conforms to the opinions of all the prominent Schools of Islamic law that "the salam sale is concluded with the word al-bay ' and/or any expression derived from it". In commercial dealings, the substance, not the form, is taken into consideration.

The respective articles of the Mejelle which stipulate that 'the salam is applicable to the item which could be defined by amount and attribute' conform to the views of all the prominent Schools of Islamic law. Unlike the view of the Hanafi School, the majority opines that the salam in animals is valid. Concerning this issue, no discussion is made in the articles of the Mejelle. The authors prefer the stand of the majority and hereby suggest that such issue may be resolved in the Mejelle by providing the required article(s) in the related section.

There is no disagreement between the related articles and the stands of all the schools of Islamic law that the salam commodity should be defined and known by volume, weight, yard, counting, etc. The majority opines that the salam commodity should be available upon maturity, while the Hanafi School

82 Al-Yahri, Wafa'a Bader, Elsiefy, Elsayed \& Abdulazeem, Abozaid, 'Shari'ah Issues in Short Selling and Its Potential Implementation in Qatar Stock Exchange,' International Business and Management, vol. 11/1 (2015): 62-78. 
opines that it should be available upon conclusion of the contract till the maturity. The articles of the Mejelle have not resolved this issue. The authors prefer the stand of the majority and hereby suggest that, if possibility arises, this issue may be discussed in the Mejelle by adding the necessary article(s) to the related section.

The related article consents to the stands of the majority Schools of Islamic law that the salam capital should be settled on spot. The Mālikī School, however, permits to give a grace of not more than three days for the settlement. The authors prefer the opinion of Māliki School and suggest that the relevant article may be reviewed and modified accordingly. Salam contract has some notable applications in contemporary Islamic financial system, such as salam financing, parallel salam, salam șukukk, salam in short selling and so forth.

\section{REFERENCES}

Al-'Aynī, Badr al-Dīn, al-Bināyah Sharh al-Hidāyah, vol. 8 (Bayrūt: Dār alKutub al-'Ilmiyyah, 2000).

Al-Aḥmad Ibn 'Arafah al-Dussūqī, Hāshiyah al-Dussūqī 'alā al-Sharh alKabīr, vol. 4 (Bayrūt: Dār al-Kutub al-'Ilmiyyah, 2003).

Al-Bahūtī, Manșūr, Kashf al-Qinā' 'an Matn al-Iqnā', vol. 3 (Bayrūt: Dār alKutub al-'Ilmiyyah, 1997).

Al-Bukhārī, Șah̄ịh al-Bukhārī, vol. 2 (Bayrūt: Dār al-Kutub al-'Ilmiyyah, 2002).

Al-Fatāwā al-Hindiyyah fi Madhhāb al-Hanafiyyah, vol. 3 (Bayrūt: Dār alFikr, 2010).

Al-Ḥaț̣āb, Abū 'Abd Allāh Muḥammad, Mawāhhib al-Jalīl li Sharḥ Mukhtaṣar Khalīl, vol. 6 (Bayrūt: Dār al-Kutub al-'Ilmiyyah, 1995).

Ibn 'Ābidīn, Muhammad Amīn, Radd al-Muḥtār 'alā al-Durr al-Mukhtār, vol. 7 (Bayrūt: Dār Iḥyā’ al-Turāth al-‘Arab̄i, 1998).

Ibn al-'Arabī, Abū Bakr Muhammad ibn 'Abd Allāh, Ahkām al-Qur'ān, vol. 1 (Bayrūt: Dār al-Kutub al-'Ilmiyyah, 1997).

Ibn Ānas, Mālik, al-Muwațtā', vol. 2 (Morocco: Dār al-Āfāq al-Jadīdah, 1998).

Ibn Nujaym, al-Bahr al-Rā'iq Sharh Kanz al-Daqā'iq, vol. 6 (Bayrūt: Dār alKutub al-'Ilmiyyah, 1997).

Ibn Qudāmah, Abī Muḥammad 'Abd Allāh Ibn Aḥmad Ibn Muḥammad alMaqdis̄̄, al-Mughnī al-Sharh al-Kab̄̄r, vol. 5 (Qāhirah: Dār al-Ḥadīth, 2004). 
Ibn Rushd, Abū al-Walīd Muhammad ibn Aḥmad, al-Muqaddimāt alMumahhidāt, vol. 2 (Bayrūt: Dār al-Gharb al-Islāmī, 1988).

Ibn Rushd, Muḥammad ibn Aḥmad ibn Muḥammad, Bidāyah al-Mujtahid, vol. 2 (Bayrūt: Dār al-Kutub al-'Ilmiyyah, 2003).

Ibn Taymiyyah, Majmū 'ah al-Fatāwā, vol. 20 (Miṣr: Dār al-Wafā', 1997).

International Centre for Education in Islamic Finance, Sharī'ah Rules in Financial Transactions (Kuala Lumpur: INCEIF, 2011).

Kamāl Ibn al-Humām, Sharḥ Fatḥ al-Qad̄̄r, vol. 7 (Bayrūt: Dār al-Kutub al'Ilmiyyah, 1995).

Al-Kāsānī, 'Alā' al-Dīn Abū Bakr, Badā 'i ‘ al-Șanā 'i ‘ fi Tartīb al-Sharā' 'i ', vol. 7 (Qāhirah: Dār al-Ḥadīth, 2005).

Khairi Saat, Mohamad, Understanding Islamic Capital Market (Kuala Lumpur: IBFIM, 2014).

Al-Kharshī, Muḥammad ibn 'Abd Allāh, Sharh al-Kharshī 'alā Mukhtaṣar Khalīl, vol. 6 (Bayrūt: Dār al-Kutub al-'Ilmiyyah, 1997).

Al-Majallah (Bayrūt: al-Maṭba'ah al-Adabiyyah, 1302H).

Al-Mardāwī, 'Alā al-Dīn, al-Inșāf fi Ma'rifat al-Rājiḥ min al-Khilāf 'alā Madhhab al-Imām Aḥmad ibn Hanbal, vol. 5 (Bayrūt: Dār al-Kutub al'Ilmiyyah, 1997).

Al-Marghīnānī, 'Alī Ibn Ab̄̄ Bakr, al-Hidāyah with al-Bināyah (Bayrūt: Dār al-Kutub al-'Ilmiyyah, 2000).

Al-Māwardī, Abū al-Hasan, al-Hāwī al-Kabīr fì Fiqh Madhhab al-Imām alShāfi 'ì, vol. 5 (Bayrūt: Dār al-Kutub al-'Ilmiyyah, 1999).

Ministry of Awqāf and Islamic Affairs, al-Mawsū'ah al-Fiqhiyyah, vol. 25 (Kuwait: Ministry of Awqāf and Islamic Affairs, 1992).

Mūsā, İthār, 'Nūṣūṣ wa Mawārid Majallat al-Aḥkām al-'Adliyyah fī Sūrriyā', https://www.mohamah.net/law, accessed on 12 November 2020.

Al-Nawawī, Yahyā Ibn Sharf al-Dīn, Rawọdah al-Ṭālibīn, vol. 3 (Qāhirah: alMaktabah al-Tawfiqiyyah, 2000).

Al-Qalīyūbī wa 'Amīrah, Shihāb al-Dīn, Hāshiyat al-Qalīyūbī wa 'Amīrah, vol. 2 (Bayrūt: Dār al-Kutub al-'Ilmiyyah, 2003).

Al-Qarāfì, Shihāb al-Dīn, al-Dhakhīrah fì Furū 'al-Mālikiyyah, vol. 4 (Bayrūt: Dār al-Kutub al-'Ilmiyyah, 2001).

Al-Sajistān̄̄, Sulaymān Ibn al-Ash'ath, Sunan Abī Dāwud (Bayrūt: Dār Ibn Hazm, 1997). 
Securities Commission Malaysia, The Islamic Securities (Sukuk) Market (Kuala Lumpur: Securities Commission Malaysia, 2009).

Al-Sharbīnī, Shams al-Dīn Muḥammad Ibn al-Khaṭīb, Mughnī al-Muhtāj ilā Ma 'rifat Ma 'ānī Alfāz al-Minhāj, vol. 3 (Qāhirah: Dār al-Hadīth, 2006).

Al-Shīrāzī, Abū Isḥāq, al-Muhadhdhab fi Fiqh al-Imām al-Shāfi 'ī, vol. 2 (Bayrūt: Dār al-Kutub al-'Ilmiyyah, 1995).

Tyser, C.R., Demetriades, D.G. \& Effendi Ismail Haqqi, 'Forward', by S. A. Rahman, H. Pk., in The Mejelle; being an English Translation of Majallah al-Ahkām al-'Adliyyah and A Complete Code on Islamic Civil Law (Lahore: Law Publishing Company, n.d.).

Al-Yahri, Wafa'a Bader, Elsiefy, Elsayed \& Abdulazeem, Abozaid, 'Shari'ah Issues in Short Selling and Its Potential Implementation in Qatar Stock Exchange,' International Business and Management, vol. 11/1 (2015): 62-78.

Al-Zayla'̄̄, Jamāl al-Dīn Abū Muḥammad, Naṣb al-Rāyah li Ahāàìth alHidāyah, vol. 4 (Bayrūt: al-Maktab al-Islāmī, 1393 AH). 